\title{
Histochemical Studies on the Distribution of Alkaline Phosphatase in Early Human Embryos.
}

\section{Observations on an Embryo with 13-14 Somites.}

\author{
幼萑人胎児におけるアルカリ性フォスファタ一ゼ分布の組織化学的研究.
}

\section{13-14 你節胎第における観察。}

Tom MORI 森富.

(Received June 13, 1959.)

As was mentioned in the foregoing report (MORI 1959), the purpose of this study is to give a detailed description of the distribution of alkaline phosphatase activity in the outstanding organs and organsystems of human embryos in the early developmental stages, and the initial step was made by a survey on the youngest specimens in our collection. This report, as the second of the series, presents similar observations on an embryo belonging in an earlier stage of the age group XI of STREETER's horizon (1942). Together with two embryos on which the preceding paper was concerned, and with the embryos I, II and III described by ROSSI and REALE (1957), this embryo, No. 121 of our collection, is one of the youngest human embryos ever used for the histochemical purpose. For this very young and wellpreserved embryo, I am greatly indebted to Dr. OHWARA, who was kind enough to fix the specimen in chilled acetone immediately after the gynecological operation and sent it to our laboratory without delay.

The specimen was then imbedded in paraffin, and cut serially into transverse sections $5 \mu$ thick. As in the preceding report, incubation was carried out without previous deparaffinization for 3 hours at $37^{\circ} \mathrm{C}$. in GOMORI's revised incubation mixture containing sodium- $\beta$-glycerophosphate as the substrate. No counter-stain was applied on these sections.

\section{Observations.}

This embryo was seemingly in the same stage of development as the famous embryo 'Pfannenstiel III' listed in KEIBEL and ELZE's 'Normentafel' (1908) and re-studied by LOW (1908), but somewhat less advanced than the 14 somite-embryo described by HEUSER (1930).

As for the somite, 14 were counted on the left side, while on the right only 13 were counted. As is shown in the Fig. 1 illustrating the ventral view of this specimen, the mid-gut communicated with the yolk sac by a wide opening. The heart was $\mathrm{S}$ shaped, and the pericardium bulged out ventrally just under the rostral end of the fore-brain. Both the cranial and caudal neuropores were still open. 


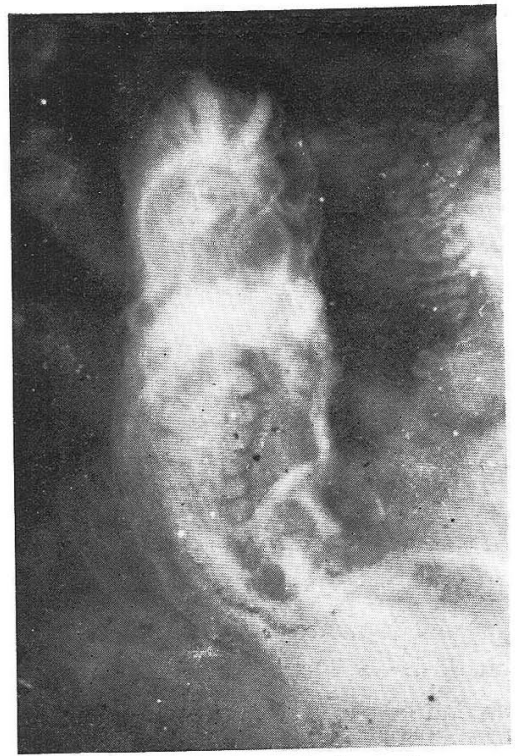

Fig. 1. Ventral view of the embryo no. 121. Photographed in benzene after dehydration with acetone. $\times$ ca. 50 .
Neural tube. In sections, the neural folds were found fused into a tube from the transverse level through the caudal part of the otic plate to the level of the last pair of the somites. The wall of the neural tube was very like a stratified columnar epithelium in histological appearance, and was composed of several layers of columnar cells having long cytoplasmic processes. A very intense activity of alkaline phosphatase was detected in the nuclei and the cytoplasm of these radially arranged cells including their fibrous processes. In most sections, the floor and the roof of the tube were slightly thinner than the side wall. However, no difference of enzymic activity was perceived either in the thick side wall or in the thinner floor and roof.

The mid-brain was just under the crown of the cranial flexure of this embryo, and was clearly separated by two distinct constrictions, the rostral and caudal, from

the fore-brain and the hind-brain (Fig. 4). Rostral to the former constriction, the neural folds were laterally expanded forming the optic evagination (Figs. 2 and 4). The latter constriction, on the other hand, was interpreted to correspond to the isthmus and the subsequent first hind-brain segment (' $r h A^{\prime}$ ) (Fig. 5), which was followed in succeeding sections by the the third rhombomere ('rh 3') showing a markedly onlarged groove (Fig. 6), and then by the fourth rhombomere ('rh 4') containing a deep narrow groove (Fig. 7).

The shape of the central canal of the spinal cord was in rather narrow slit-like form with its longer axis in a ventro-dorsal direction till the level of the 3rd or 4th somite (Figs. 10 and 11), but caudally, the canal became elliptic, the regional difference in the thickness of the wall of the neural tube becoming less apparent (Figs. 12 and 13).

Notwithstanding such a cephalo-caudal gradient of differentiation, the advanced segmentation of the brain part and the delaied differentiation of the medullary part, an almost even and uniform staining was demonstrated throughout whole area of the central nervous system.

Neural crests. The most rostral one of the neural crests found in this specimen was a small mass of highly stained cells attached to the dorsal wall of the left optic evagination (Fig. 2). In some sectiong, this cellular mass was found apparently in direct connection with the neural epithclium without interposition of the outer limiting membrane of the latter (Fig. 3). From such a figure, the impression was gained of an emigration of the neuroblasts from the optic anlage. Dorsally, on the other hand, the cell-mass was seemingly continued to the anterior end of the rostral neural 
crest, too. On the right side, no such a cell-mass was found.

The rostral neural crest of this embryo was found forming a very large cellular mass in the cranial mesoderm lateral to the mid-brain and the most anterior part of the hind-brain (Figs. 2, 4 and 5). The cells of this neural crest were large and angular in shape, and syncytically connected with one another by their cytoplasmic processes. The activity of alkaline phosphatase was very intense throughout their nuclei and cytoplasm. In the extent of this neural crest, at least two branchings were already discernible: the one extending rostrally along the side wall of the mid-brain, and on the left side of the specimen, as described above, coming in contact with a small cellular mass at the behind of the optic evagination (Figs. 2 and 4): and the other extending caudally from the main mass of the neural crest cells and deeply penetrating into the mandibular process (Figs. 5-7). In the greater part of this neural crest, the connection of cells was rather loose, some of them being detached from the mass and migrating into the mesoderm. Most of these isolated neural crest cells were readily distinguishable from the mesoblasts by an intense enzymic activity, while the latter mostly showed only a faint reaction. But the moderately stained cells scattered around the neural crest were sometimes not easy to decide in which cell-type they belonged.

The acoustico-facial neural crest formed a large, hemispherical, compact cellular mass bulging out from the side wall of the hind-brain over the distance from the caudal part of the 'rh 3' through the 'rh 4' (Figs. 7 and 8). Not only by the intense blackening but also by the sharp outline of the mass, the boundary of this neural crest was very clearly defined from the surrounding mesoderm. No direct connection of this neural crest with the otic plate was confirmed.

In more caudal sections ranging from the rear of the otic plate, there was a few number of minute neurl crests. This may be assumed as the post-otic neural crest, and the migrating neural crest cells were clearly discriminated from the mesodermic cells by an intense phosphatase activity (Fig. 9).

The spinal neural crest were also observed in the extent from the level of the 1st somite to that of the 5 th somite. Most of them were represented by the heavily stained thin cell-alignments extending ventro-laterally from the dorsal wall of the spinal cord (Figs. 10 and 11).

Integumentary ectoderm and placodes. The largest part of the surface ectoderm was composed of single layer of low cuboidal or squamous epithelial cells except some specific areas of the integumentum, the placodes, which consisted of high columnar cells. Among the latter, the otic plate was most outstanding by its thickness and its sharp outline (Fig. 8). However, a high activity of the enzyme was evenly detected throughout in these thick placodes and in the thin skin ectoderm.

Gut. As described above, the mid gut opened out into the yolk sac cavity. The mid-dorsal roof of the major part of the gut was intercalated by the notochord.

The rostral end of the fore gut was still closed. In the pharynx, three branchial pouches were visible: the first being deep, the second and the third shallow and still rudimentary. The lumen of the pharynx was markedly flattened laterally. The dorsal wall consisted of a layer of low cuboidal cells, and at the midst, it was slightly intended dorsalward and formed a shallow furrow containing the notochord in its 
bottom. The ventral wall, on the other hand, was thick, and, at the level of the second branchial bar, protruded the anlage of the thyroid gland towards ventral (Fig. 8). At the back of the sinus venosus, in the extent from the level of the 2 nd somite to that of the 3rd somite, the middle part of the floor of the fore-gut was highly thickened and showed very intense staining. This restricted thick area of the gut endoderm may be deemed as the first anlage of the lung. In more caudal sections through the rostral intestinal portal, the liver primordium was found as a marked thickening of the endodermic epithelium (Fig. 11). An even and high activity of the enzyme was detected throughout in the whole area of the thin dorsal and thick ventral walls including primordia of the thyroid, lung and liver.

In the mid-gut, the epithelial cells lining the gut cavity also showed an intense enzymic activity (Figs. 12 and 13).

The hind-gut was circumscribed by a rather thick epithelium except at the considerably wide notochordal plate occupying the middle of the dorsal roof of anterior two thirds. The epithelial cells of the hind-gut were also stained intensely, including those of the allantois (Figs. 14 and 15).

Notochord. The largest part of the notochord was still found inserted into the dorsal roof of the gut. The dorsal surface of it closely attached to the bottom of the neural tube. In the sections ranging from the level of the 1st pharyngeal pouch to that of the 6th or 7th somite, the cells of the notochord were arranged in a dorsally convex archade form (Figs. 6-12). But below the latter level, the notochord became an epithelial plate slightly indented dorsalward (Figs. 13 and 14), and more caudally, it was separated from the dorsal wall of the hind-gut and turned into an epithelial tube containing a minute canal (Fig. 15), and then into a solid cell-cord which finally fused with the primitive streak (Fig. 16).

In the major part of the notochord, very faint or only a negligible staining was observed in both the nuclei and the cytoplasm. But, in the epithelial tube and the cell-cord (Head process) overlying the hind-gut, a moderate reaction was demonstrated which gradually intensified in the succeeding sections until it reached nearly the same intensity of the caudal mass of the mesoblasts and the primitive streak.

The prochordal plate was not so definitely discerned as in the embryo 101, but, an unstained cellular mass covering the rostral tip of the pharynx and further protruding a little above it (Figs. 5 and 6) may be deemed as the prochordal plate. As illustrated in Fig. 5, there was a narrow link between this prochordal plate and the cranial mesoderm, both of which showed no phosphatase activity.

Mesoderm. In the mesodermic layer, a caudo-cranially graded staining was also observed as in the case of the younger embryos previously described. The cranial unsegmented mesoderm above the 1st somite mostly showed no or only a faint reactivity (Figs. 4-9). The very little 1 st somite itself remained almost unstained. At the level of the second somite, the epithelially arranged cells of the axial mesoderm were reactive, but their staining intensity was, as shown in Fig. 10, far below that of the cells in the neural tube or in the gut wall. In the sections through the anterior two or three somites, a definite enzymic activity was sometimes revealed in the narrow intermediate portion connecting the axial mesoderm and the lateral plate (Fig. 10). This will be reconsidered below. 
As the mesoderm was traced caudalward until the level of the 3rd somite, a definite activity of the enzyme was detected throughout in the somite, the lateral plate and the segment stalk (Fig. 11). This activity was found further increased in the succeeding levels, and in the sections caudal to the 5 th or 6 th somite reached a similar intensity as in the neural epithelium (Fig. 12). But, at the lateral boundary of the lateral plate adjoining the extraembryonic mesoderm, a sudden decrease of the enzymic activity was noticed. By this abrupt depression of stainability, the boundary between the intra- and extraembryonic parts of the mesoderm was clearly defined.

The caudal unsegmented mesoderm and the prmitive strea's also showed even and very intense reaction (Figs. 14-16).

The nephrogenic structure of this specimen loo:s considerably advanced than in the embryo 101. Over the distance from the level of the 1st somite to that of 3rd somite, each primitive segment stalk formed an ovoid cell-mass containing a minute cavity, which was partially in communication with the lateral coelom through a narrow passage projected from the latter. Such a small vesicular formation may be regarded as the nephrotome, and the narrow communication with the coelom as the peritoneal funnel described by TORREY (1954). Besides, a similar additional structure was observed just cranial to the 1 st somite on the left side of the embryo. As mentioned above, mesodermic cells forming such a nephrotome, the peritoneal funnel and the adjacent area of the splanchnopleura showed more or less definite enzymic activity.

In this specimen too, as in the case of the embryo 101, a thin cell-cord projected dorsally from the left segment stalk at the level of the 7th somite (Figs. 12, 17 and 18).

In addition to the above, the nephrogenic cord was also found as an elevation of the dorso-median ragion of the lateral plate in the posterior part of the body (Fig. 13). As an even and intense tinting was detected in the mesodermic layer more caudal than the middle level of the somitic region, no noticeable difference of reactivity was perceived between the nephrogenic cord and the remaining coelomic epithelium from which the former had protruded. On the left side, the rostral end of the nephrogenic cord was found at the level of the middle of the 10th somite, and caudally, it became gradually more prominent, and finally merged in the unsegmented caudal mesoderm at the level of the 14 th somite. It contained small discrete cavities which were connected with the lateral coelom through narrow peritoneal funnels at the levels of the 10th, 11th and 12th somites. On the right, a similar elevation of the lateral mesoderm could be traced cranially to the level just caudal to the 9th somite and caudally to that of the 13th somite, behind which it fused with the caudal mesoderm. The lumen contained was also connected with the coelom by narrow passages, the levels of which did not correspond with that of the respective somite. In the sections through the 11 th and 12 th somites, the nephrogenic cord on both sides seemed to be somewhat disengaged from the coelomic epithelium, but this separation was still incomplete (Fig. 19).

In the mesodermic layer surrounding the ventral wall of the hind-gut, the allantoic duct and the posterior part of the yolk sac adjoining the former two, a few primordial germ cells were found scattered. As in the embryo 103, they were charac- 
terized by an intensely stained large round nucleus.

The endothelial cells of blood vessels including an S-shaped endocardium, aortic arches, dorsal aortae and umbilical veins still remained almost colorless. The primordial pericardium and the considerably thick myocardium were also stained only negligibly. But the still epithelial splanchnopleura covering the atrium and the sinus venosus exhibited diffuse and moderate staining (Fig. 10).

\section{Discussion and Summary.}

In this embryo, a definite and intense activity of the alkaline glycerophosphatase was detected in the whole area of the nerve anlage, the surface ectoderm including several placodes, the gut endoderm, and the mesoderm below the transverse level of the 3rd somite. Such an enzymic pattern is in good conformity with similar observations on the embryos of horizon X (MORI 1959) and a $2.7 \mathrm{~mm}$ embryo (ROSSI and REALE 1957). Furthermore, this enzymic pattern also agrees in major part with that described by MULNARD (1955) on the rat embryos of 10 and 11 days of pregnancy, except some dissimilarities in the surface ectoderm and the lateral plate of mesoderm, both remained colorless in rat according to MULNARD.

In this observation, only an even staining was revealed throughout these primitive organs here mentioned, no remarkable localization of the enzyme being discernible notwithstanding the appearance of the anlages of such definitive organs as the thyroid gland, lung, liver, otic plate and nephric duct. For this diffuse enzymic pattern, rather long ( 3 hours) incubation of the specimen in the substrate mixture may also be responsible.

In the neural crests, some changes of stainability was perceived, particularly in the rostral neural crest. In this neural crest, at least some cells seemed to be just beginning to lose their specific phosphatase activity. Such a reduction of the enzymic activity of the neural crest cells becomes more apparent in older embryos, as it will be described in the subsequent paper dealing with those belonging in horizon XII. A small mass of the neural crest cells attaches to the behind of the left optic evagination may presumably be the optic neural crest, on which a comprehensive account has been made by BARTELMEZ and BLOUNT (1954).

In good agreement with observations on the embryos belonging in horizon $\mathrm{X}$, the major part of the notochord, the cranial mesoderm and the extraembryonic mesoderm of this embryo did not stain. As was discussed in the foregoing paper, neverthless, it is very certain that an active proliferation of cells is still in progress in these unstained tissues, too. Unlike those tissues showing a prominent stainability, however, it may be pointed out as a common characteristics of these unstained tissues that from any of them no definitive organs having a different character and structure may be derived in the future development. From these findings, though it is nothing beyond hypothesis, it seems that not only the proliferating activity but also a potentiality of future differentiation is related to some extent to the activity of this enzyme. 


\section{内 容 自 抄.}

Streeter's horizon XI の初期に該当する 1 胎芽（13-14 倈幯）におけるアルカ リ性フォスファターゼ活性の分布を組織化学的にしらべた。強い反応は神経管, 神経節原基, 腸管壁 (それより形成されつつある甲状腺, 肺, 朋の初期の原基を含 む)。第 3 㑂節以下の中胚葉, 原始線条, 原始生殖細胞にみられた。一方, 脊索の大 部分, 頭部の巾肧葉, 胎児外の川肧葉, 心臟原基は殆ど反応を示さない. 叉, crista neuralis rostralis では細胞の散乱があり，且つ，一部の細胞では反応が減弱し 始 めているのが見られた。

\section{References.}

Bartelmez, G. W. and M. P. Blount: The formation of neural crest from the primary optic vesicle in man. Contr. to Embryol. 35 (1954). P. 55 . -- Heuser, C. H.: A human embryo with 14 pairs of somites. Contr. to Embryol. 22 (1930). P. 135 . - Keibel, F. und C. Elze: Normentafel zur Entwicklungsgeschichte des Menschen. Jena, Gustav Fischer, 1908. - Low, A.: Description of a human embryo of 13-14 mesodermic somites. J. Anat. Physiol. 42 (1908). P. 237. - Mori, T.: Histochemical studies on the distribution of alkaline phosphatase in the early human embryos. I. Observations on two embryos in early somite stage, Streeter's horizon x. Arch. hist. jap. 16 (1959). P. 169 . - Mulnard, J.: Contribution à la connaissance des enzymes dans l'ontogénèse. Les phosphomonoestérases acide et alcaline dans le développement du rat et de la souris. Arch. Biol. 66 (1955). P. 525. — Rossi, F. and E. Reale The somite stage of human development studied with the histochemical reaction for the demonstration of alkaline glycerophosphatase. Acta Anat. 30 (1957). P. 656 . Streeter, G. L. : Developmental horizons in human embryos. Description of age group xi, 13 to 20 somites, and age group xii, 21 to 29 somites. Contr. to Embryol. 30 (1942). P. 211.

- Torrey, T. W.: The early development of the human nephros. Contr. to Embryol. 35 (1954). P. 175. 


\section{Explanation of plate-figures.}

Fig. 2. Section 14 through the cranial flexure of the specimen. An anterior part of the mid-brain and a part of the optic evagination are cut through. The rostral neural crest attaches to the mid-brain fold on either side. On the right side of the figure, a small triangular mass of neural crest cells is visible at the behind of the optic evagination. $\times 75$.

Fig. 3. High magnification of the right half of the same section illustrated above. $\times 300$.

Fig. 4. Section 28 through the mid-brain. The rostral neural crest attaches to the caudal constriction, the isthmus, and extends rostrally along the mid-brain. $\times 75$.

Fig. 5. Section 54 through the first hind-brain segment, the rostral end of the pharynx and the fore-brain. The tip of the pharynx is covered by an unstained cell-mass, that is the prochordal plate. It links dorso-laterally with the cranial mesoderm through a narrow cellbridge. The cells of the rostral neural crest are loosely connected with one another and migrating into the mesoderm. $\times 75$.

Fig. 6. Section 60 through the $3 \mathrm{rd}$ rhombomere, a cranial part of the pharynx and the rostral end of the fore-brain. The most anterior part of the prochordal plate is seen between the ventral wall of the pharynx and the fore-brain. Highly stained cells of the rostral neural crest are migrating into the mandibular process. $\times 75$.

Fig. 7. Section 73 through the 4 th rhombomere and a cranial part of the acoustico-facial neural crest. The pharynx is cut at the level of the second pouch. In the right mandibular bar, some rostral neural crest cells are seen. $\times 75$. 

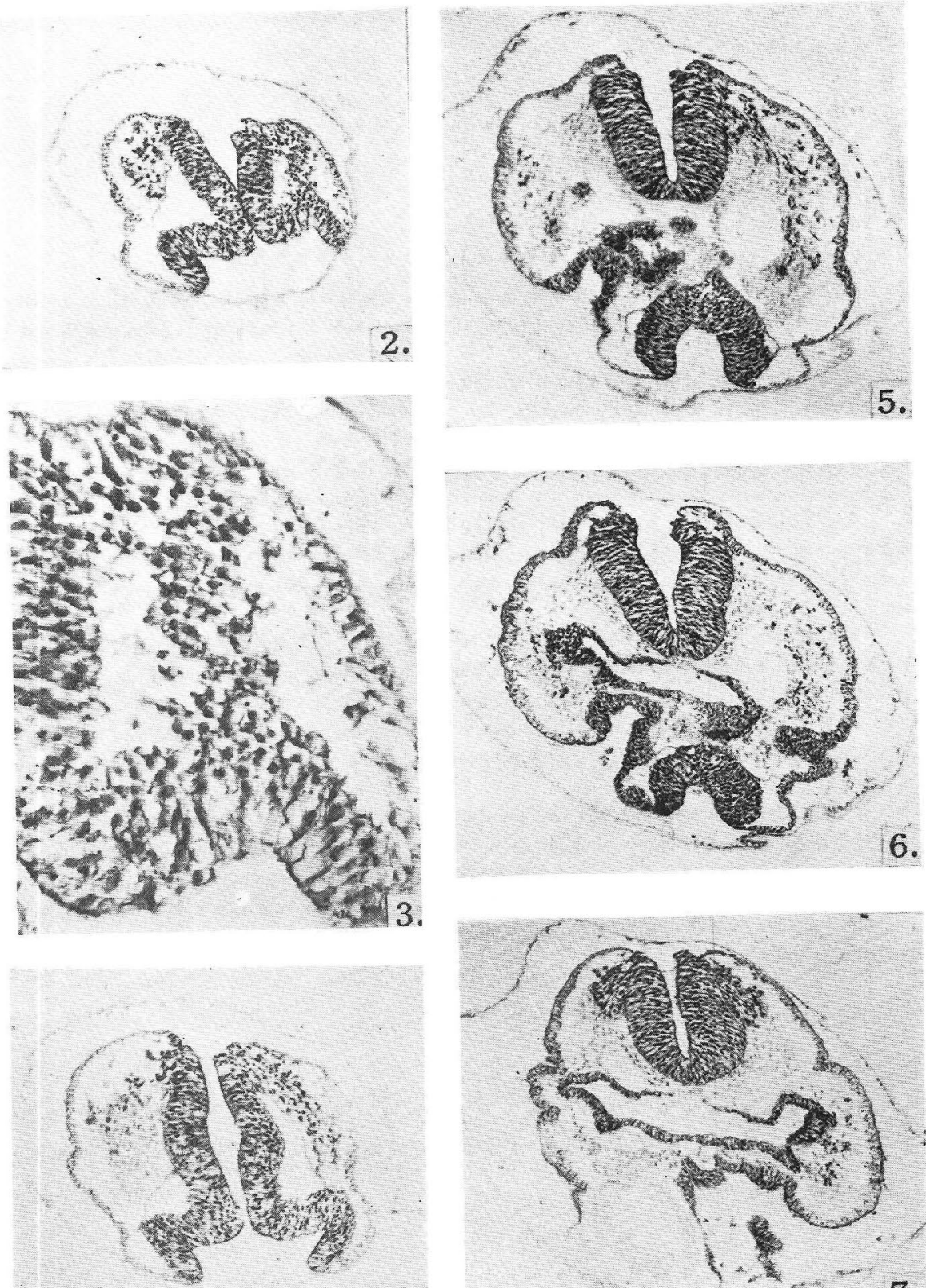

4.

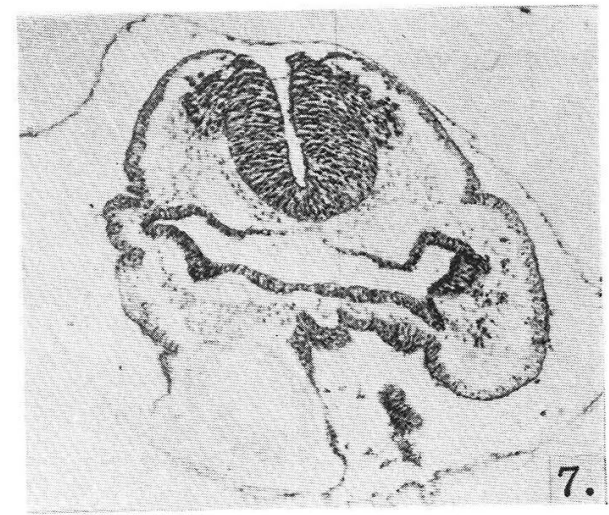


Fig. 8. Section 90. The large and compact acoustico-facial neural crest attaches to the lateral wall of the rhombencephalon. From the ventral wall of the pharynx, the middle thyroid anlage protrudes. $\times 75$.

Fig. 9. Section 128 through somewhat cranial to the 1 st somite. The cells of the postotic neural crest are migrating ventrally along the side wall of the hind-brain. The endocardium, pericardium and myocardium do not stain. $\times 75$.

Fig. 10. Section 150. The somite on each side is the 2 nd, and stains very faintly. The splanchnopleura covering the sinus venosus exhibits a faint reaction. $\times 75$.

Fig. 11. Section 173 through just cranial to the anterior intestinal portal. The mesoderm is moderately stained including the somite (the $3 \mathrm{rd}$ on the left and the 4 th on the right) and the lateral plate. The liver anlage forms a highly stained thick part of the endoderm at the intestinal portal. $\times 75$.

Fig. 12. Section 219, showing an enhanced reaction of the mesoderm at the middle level of the somitic region. As for the somites, the 5 th and 6 th are seen on the left, and 6 th and 7 th on the right. The right 7 th somite links with the segment stalk, from which a thin cellcord projects dorsally. An abrupt depression of the staining at the lateral border of the lateral plate makes a clear-cut delimitation between the intra- and extraembryonic parts of the mesoderm. $\times 75$.

Fis. 13. Section 288, showing an even and intense staining of the mesoderm at the caudal level of the somitic region. The somite on the left is the $10 \mathrm{th}$, and those on the right are the 12 th and the $13 \mathrm{th}$, the latter being in connection with the segment stalk. The dorso-median part of the lateral plate elevates dorsally forming the nephrogenic cord. A small lumen contained in the cord on either side is in communication with the lateral coelom through a slit-like passage. $\times 75$. 
T. MORI (2)
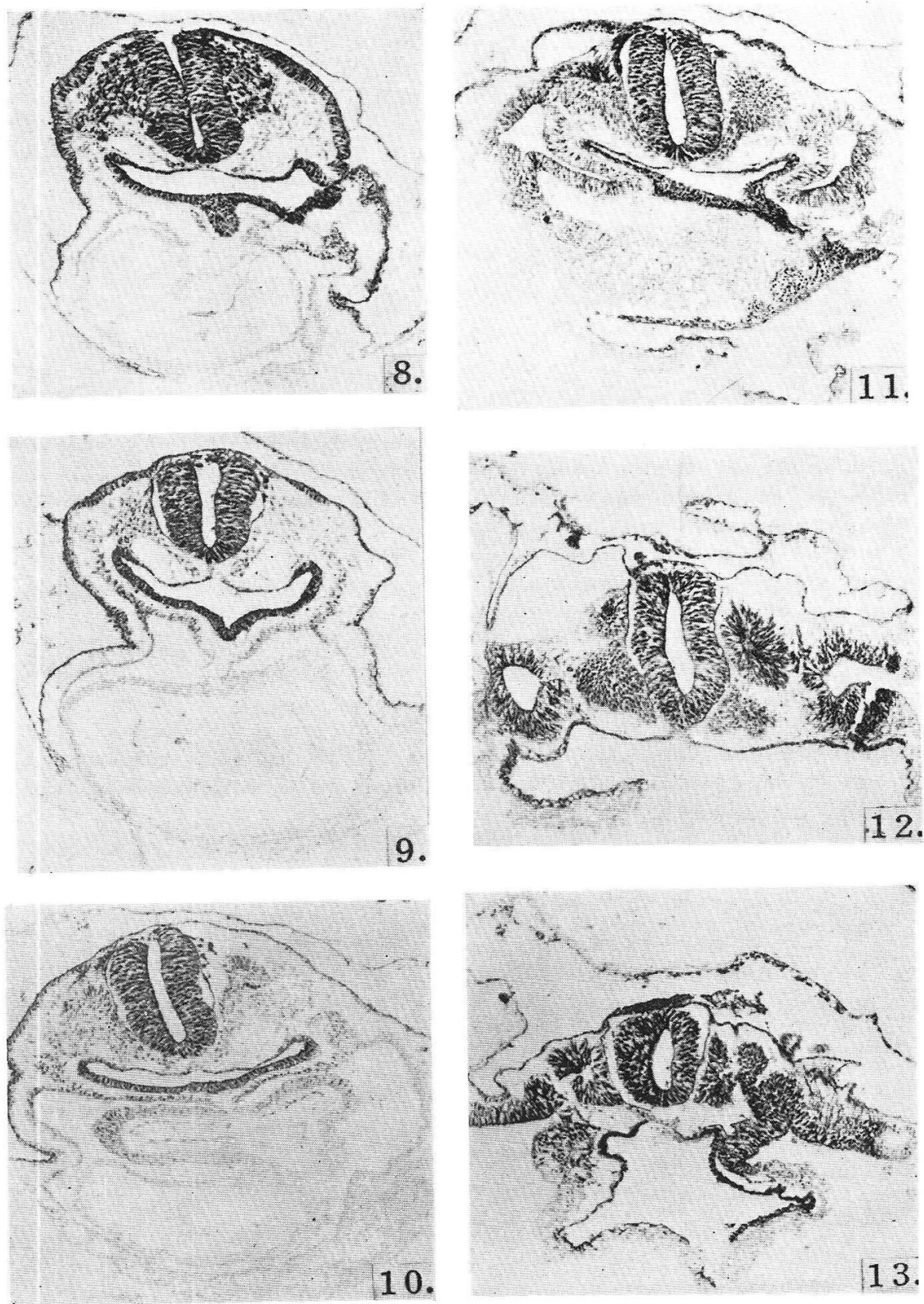
Figs. 14-16. Sections 336, 350 and 360 through the caudal portion of the specimen. The major part of each section is uniformly and intensely stained. The notochord is found as a faintly stained epithelial plate forming the mid-dorsal roof of the hind-gut in the Fig. 14, and it becomes a moderately stained epithelial tube overlying the gut in Fig. 15, and it finally fuses with the primitive streak in Fig. 16 . $\times 75$.

Figs. 17 and 18. Higher magnification of the right segment stalk at the level of the 7 th somite. Fig. 18 is the partial magnification of the section illustrated in Fig. 12, and Fig. 17 shows the same part in the adjacent section (no. 218). This structure, the thin cell-cord projecting from the segment stalk, is very similar to that found in the 8 somite-embryo described in the preceeding paper, and may tentatively be interpreted as a rudimentary pronephric tubule. $\times 300$.

Fig. 19. The right half of the section 277. The nephrogenic cord is separated from the coelomic epithelium (lower right). The somite connecting with the segment stalk is the 12th, and the one on the left is the 11th. An even and intense activity of the enzyme is demonstrated in the mesoderm. $\times 300$. 

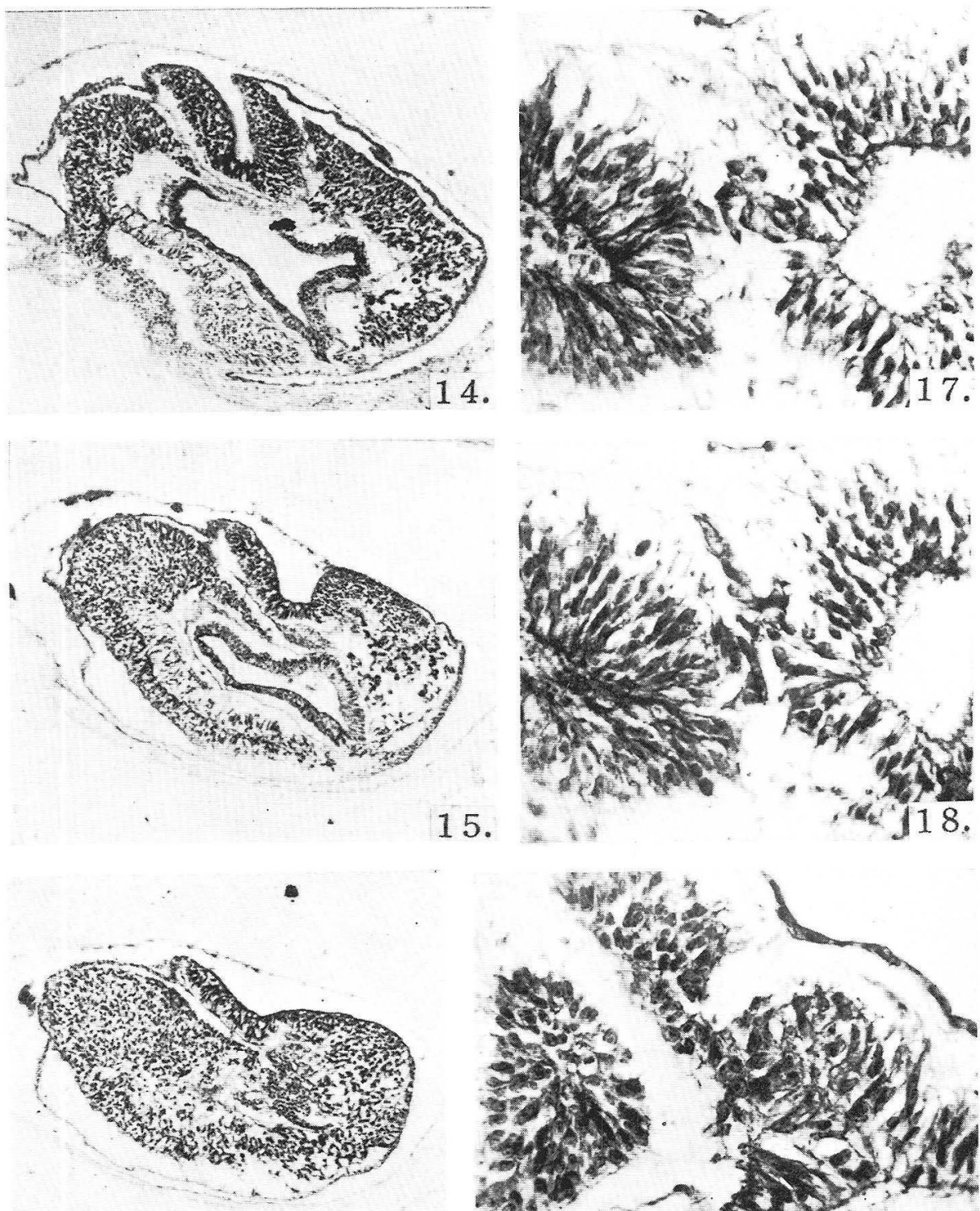

15.

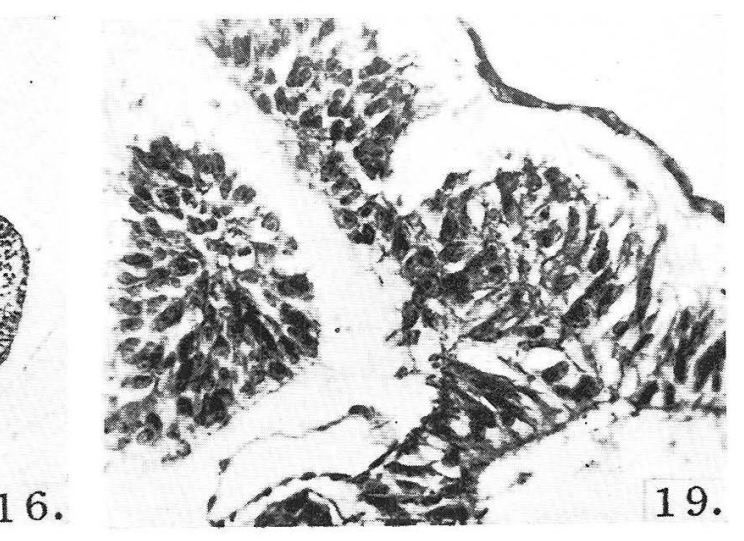

